\title{
A risk prediction model of the incidence of occupational low back pain among mining workers
}

\author{
Fikry Effendi, ${ }^{1}$ Corrie Wawolumaja, ${ }^{1}$ Azrul Azwar, ${ }^{1}$ Jusuf Misbach ${ }^{2}$ \\ ${ }^{1}$ Department of Community Medicine, Faculty of Medicine, University of Indonesia \\ ${ }^{2}$ Department of Neurology, Faculty of Medicine, University of Indonesia
}

\begin{abstract}
Abstrak
Latar belakang: Nyeri Punggung Bawah (NPB) merupakan kelainan muskuloskeletal yang paling sering terjadi akibat kerja. Penelitian ini bertujuan mengembangkan model prediksi risiko kejadian NPB akibat kerja.

Metode: Penelitian ini menggunakan disain kasus kontrol berbasis komunitas industri dengan pendekatan ergonomi. Jumlah sampel adalah 91 orang pada kelompok kasus dan 91 orang pada kelompok kontrol. Kasus adalah pekerja yang terkena NPB dalam enam bulan terakhir, sedangkan kontrol adalah pekerja yang tidak terkena NPB dan mempunyai pajanan serta golongan umur yang sama. Faktor risiko yang diteliti adalah faktor sosio-demografi, sosio-okupasi, lingkungan kerja fisik dan non-fisik dan biomekanika. Kurva Receiver Operating Characteristics (ROC) digunakan untuk mencari nilai prediksi hubungan angka positif benar (pada sumbu tegak) dengan angka positif palsu (pada sumbu horizontal).

Hasil: Faktor risiko determinan kejadian NPB adalah sikap kerja janggal membungkuk, sikap kerja janggal memutar pinggang, sikap kerja janggal angkat angkut secara manual, postur kerja tidak alamiah, masa kerja di atas 18 tahun, dan kebiasaan olahraga tidak teratur. Melalui analisis kurva ROC pada tingkat sensitivitas $91,20 \%$ dan spesifisitas $87,90 \%$ didapat nilai prediksi 0,35. Nilai ini adalah cut off point untuk membedakan pekerja yang sakit (NPB akibat kerja) dengan yang tidak sakit. Nilai prediksi risiko kejadian NPB akibat kerja dapat diketahui berdasarkan persamaan linier regresi logistik dan bervariasi antara 0 dan 11,25.

Kesimpulan: Model prediksi ini dapat dipakai sebagai instrumen deteksi dini kejadian NPBakibat kerja dengan memasukkan instrumen ini pada instrumen medical check up (MCU), dengan demikian dapat dilakukan tindakan segera untukmengurangi risiko sehingga dapat dicegah berulangnya kejadian NPB akibat kerja. (Med J Indones. 2011; 20:212-6)
\end{abstract}

\begin{abstract}
Background: Low Back Pain (LBP) is the most frequently reported musculoskeletal disorder in workers. This study was aimed to develop risk prediction model of low back pain that can be used to prevent the recurring low back pain attack.

Methods: The study was case-control design based on the industrial community by using ergonomical approach. Total samples were 91 workers for cases and 91 workers for controls. Workers suffering for low back pain in the last 6 months served as cases, and those from the same age group and receiving the same amount of exposure without any symptoms of low back pain served as controls. Risk factors include socio-demographic factors, socio-ocupational factors, physical working environmental factors, non-physical environmental factors, and biomechanics factors. Receiver Operating Characreistics (ROC) was used to describe relationship between true positive value (in vertical axis) and false positive value (in horizontal axis) in order to discover a risk predictive value of LBP.

Results: The determinant risk factors for low back pain (LBP) were bending work postures, waist rotation movement, manual lifting, unnatural work postures, those who had worked for more than 18 years, and irregular sport activities. By using ROC with $91.20 \%$ senstivity and $87.90 \%$ spesificity, the calculated prediction value was 0.35 . This is the cut-off point to discriminate workers with and without LBP. The risk predictors value of work-induced LBP calculated by linear equation of logistic regression varied between 0-11.25.
\end{abstract}

Conclusion: The prediction model of work-induced LBP can be used for early detection of LBP to reduce the risk and prevent the recurrence of LBP.(Med $J$ Indones. 2011; 20:212-6)

Key words: Ergonomy, low back pain, prediction model, work-induced LBP

An occupational disease is defined as any disease caused by working process or working environment. Since the beginning of the $18^{\text {th }}$ century, this kind of disease has been recognized, and musculoskeletal disorder has placed itself as the most frequent cause of occupational disease. Benardini Ramazzini, also known as The Father of Occupational Medicine, stated in his book "De Morbis Artificum Diatriba (Disease of workers)", that musculoskeletal disorders were tightly related with certain occupational risk factors, which are sitting with bending position (slouching), non-upright head position, downward gaze, and monotonous working pattern. ${ }^{1-3}$

Work related low back pain (LBP), being one of the most frequently reported musculoskeletal disorder, is primarily found in workers doing certain physical act, such as lifting, lowering, pushing, pulling, and sustaining load. This type of disorder appears after the workers are imposed with increasing physical, as well as non-physical, workload. Symptoms including fatigue, paresthesia, back pain, and shoulder pain; are 
due to inflammation process caused by irritation or trauma in intervertebral disc, joint, ligamentum, and/ or back muscles. ${ }^{4,5}$

In order to perform proper management of LBP, risk factors need to be identified. Risk factors for low back pain are categorized into three groups of main determinants: host, agent, and environment. Such determinants will be discussed further to explore facilitation of early diagnosis and prompt treatment. ${ }^{6}$

Host factor consists of the entire physical, mental, and social condition of the worker, which further divided into two components, socio-demographic and sociooccupation. Socio-demographic components comprise of age, sex, education level, body mass index, sport activities, and smoking habit; while socio-occupation components includes type of work, duration of working activity, period of working, workplace setting, training, and compliance to the standard operating procedures. Serving as the agent of low back pain is the biomechanical factors in the working process, and defined as movements or physical actions performed during working activity. It can be divided into direct biomechanical determinants, which directly related to certain movement or action, such as bending, waist rotation movement, lifting over the shoulder, manual lifting and handling, and repetitive movements; and indirect biomechanical determinants, such as working postures, back muscle use, and period of resting. ${ }^{10,11}$ If direct biomechanical determinants occurs without proper consideration of ergonomic factor, it can create unnatural working postures which, combined with the indirect biomechanical determinants such as squatting, overuse of back muscles, and insufficient period of resting; would later on result in the occurrence of musculoskeletal disorder, including low back pain. ${ }^{7-9}$

Working environment is differentiated into physical and non-physical environment. Physical environment factors related to low back pain are noise level and vibration. While non-physical environment factor is work-related stress measured by the occurrence of role ambiguity, role conflict, workload (quantitatively or qualitatively), career development, and responsibility concerning other workers. Workers exposed to high level of stressor in the workplace would experience significant stress level and this could further cause muscle spasms, known as one of the precipitating factor of LBP. ${ }^{6,8}$

Based on previous studies, the prevalence of low back pain ranges between $38.0 \%-75.9 \%$. These studies used cross-sectional design, and has not covered the three determinants of LBP entirely. Studies concerning prediction model for the risk factors of work-related LBP as a means to perform early diagnosis and prompt treatment has not been found.
Prediction model for the risk factors of LBP is required to help avoid the occurrence and exacerbation of work-related low back pain. This model can be used as a diagnostic tool for the screening process of work-related LBP.

The aims of this study were to determine the relation of socio-demographic risk factors, socio-occupational risk factors, working environment, and biomechanical factors with the occurrence of work-related low back pain; and to invent the prediction model for workrelated LBP.

\section{METHODS}

The study was conducted in an industrial community using case-control design. Data was collected from X oil company, located in Balikpapan, East Kalimantan, Indonesia in April 2007 -May 2009. Case group consists of workers who served the company for a minimum period of 6 months with a diagnosis of workrelated low back pain based on anamnesis and physical examination. While control group consists of workers from the same department or division, within similar age group who are exposed to similar exposure and 6 years minimum work experience, without any sign or symptom of low back pain.

Using case-control formula, sample size was calculated based on $\mathrm{p}_{1}=\mathrm{p}_{0}(\mathrm{RR})$ and power $\mathrm{Z}_{1-\mathrm{B}}=0.84$ with the result of 91 respondents for each group. Data was obtained by the means of purposive sampling.

In accordance to the aim of the study, six instruments were used in data collection, which consists of questionnaire, physical examination, noise level, vibration level, work stress level, and biomechanical factors examination using Computer Aided Postural Analyses (CAPA).

Data analysis was done using univariate, bivariate, and multivariate analysis with the aid of Statistical Package for Social Sciences (SPSS) 15.0. The ROC curve was used afterwards to discover thr cut-off point for thr lowrisk and high-risk group of developing LBP by getting the highest sensitivity and specificity value. Logistic linier regression was used for prediction model of risk of work-related LBP.

\section{RESULTS}

The socio-demographic characteristics of the respondents are as follows: mean age 45 years, mean formal education level of 14 years, and mean body mass index mean of 24.87. Smoking habit was found in $29.12 \%$ respondents and $37.91 \%$ respondents performed sport activities irregularly. Socio-occupational characteristics 
revealed that $64.20 \%$ workers worked in the field, mean working period was 18 years, and spent 10.84 hours per day working. $84.62 \%$ workers performed their duty in a constricted workplace design, with none of the respondents aware of or ever undertake any training of the standard operating procedures of working ergonomically.

Unnatural working postures were found in $66.49 \%$ respondents, several movements and position with risk of developing low back pain as follows; repetitive movements in $38.46 \%$, bending in $36.26 \%$, manual lifting in $37.36 \%$, back muscle overuse in $69.78 \%$, and insufficient resting period in $57.14 \%$.

Workplace with a high noise and vibration level were experienced by $12.09 \%$, and work stress due to certain factors were as follows; role ambiguity $51.10 \%$ respondents, role conflict in $50.00 \%$, excessive quantitative workload in $53.30 \%$, excessive qualitative workload in $57.69 \%$, career development in $54.95 \%$, and responsibility to others in $62.09 \%$

Bivariate analysis revealed 13 variables with significant relation to work-related low back pain, which consists of above 45 years age group, irregular sport activities, working period of more than 18 years, constricted workplace design, unnatural working postures, repetitive movements, awkward bending, awkward waist twisting, awkward lifting over the shoulder, awkward manual lifting and handling, overuse of back muscles, insufficient resting period, and work stress due to a sense of responsibility to others.

Through multivariate analysis, six variables were found to be the main risk factors of work-related low back pain (Table 1)

Tabel 1. Multivariate analysis of six determinant for prediction of the risk LBP

\begin{tabular}{lclc}
\hline Determinant Variabel & OR & CI 95\% & P \\
\hline Ackward bending & 91.30 & $9,568-871,285$ & 0,000 \\
Irregular sport activity & 52,87 & $12,435-224,746$ & 0,000 \\
Working Posture & 26,31 & $6,029-114,842$ & 0,000 \\
Ackward waist twisting & 20,49 & $3,509-119,709$ & 0,001 \\
$\begin{array}{l}\text { Ackward manual lifting and } \\
\text { handling }\end{array}$ & 10,46 & $1,833-59,655$ & 0,008 \\
$\begin{array}{l}\text { Working period more than } \\
\text { 18 years }\end{array}$ & 5,40 & $1,856-15,704$ & 0,002 \\
\hline
\end{tabular}

Overall percentage $\mathrm{R}^{2}=74.80$

Using backward stepwise method, the logistic linear regression formula for prediction model for risk of work-related low back pain is:

$\mathrm{Y}($ work-related LBP $)=-5,94+4,51$ bending $+3,97$ sport activity $+3,27$ working postures $+3,02$ twisting + 2,35 manual lifting and handling $+1,69$ working period.
By using this formula the $\mathrm{R}^{2}$ value obtained was 0,748 with $\mathrm{p}<0.01$. The prediction model is appropriate and can predict $74.80 \%$ of LBP occurence.

Receiver Operating Characteristics (ROC) curve in reference to the highest sensitivity and specificity revealed the cut-off point of 0.35 (as shown in figure 1).

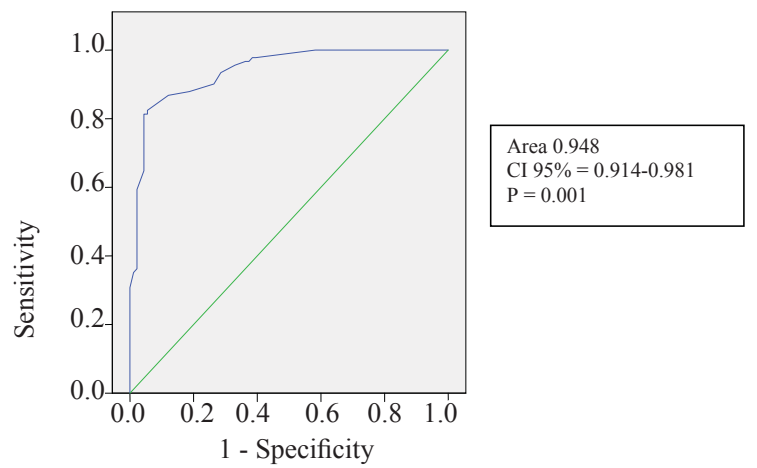

Figure 1. ROC Curve for prediction of true, work-induces LBP

Based on these findings, risk prediction value of workinduced LBP fo each respondent is analyzed using logistic regression and the result is shown in table 2 and 3.

The result in table 3 show that workers with prediction score of $\leq 3$ have low risk in developing work-related LBP while workers with prediction score $>3$ have high risk of work-related LBP.

Table 2. Prediction score for the risk of LBP

\begin{tabular}{lc}
\hline \multicolumn{1}{c}{ Variable } & Risk Prediction Score \\
\hline Awkward bending & 2,50 \\
Irregular sport activity & 2,50 \\
Unnatural working postures & 2,00 \\
Awkward waist twisting & 1,75 \\
Awkward manual lifting and handling & 1,50 \\
Working period $>18$ years & 1,00 \\
\hline
\end{tabular}

Tabel 3. Distribution of respondents based on risk level of developing work related low back pain

\begin{tabular}{cccccccc}
\hline \multirow{2}{*}{$\begin{array}{l}\text { Risk prediction } \\
\text { score }\end{array}$} & \multicolumn{2}{c}{ LBP } & \multicolumn{3}{c}{ Without LBP } & Total & \% \\
\hline Low & $\mathbf{N}$ & $\mathbf{\%}$ & $\mathbf{N}$ & $\mathbf{\%}$ & & \\
High $>3$ & 9 & 12,1 & 80 & 90,1 & 89 & 48,9 \\
\multicolumn{2}{c}{ Total } & 82 & 87,9 & 11 & 9,9 & 93 & 51,1 \\
& 91 & 100,0 & 91 & 100,0 & 182 & 100,0 \\
\hline
\end{tabular}

\section{DISCUSSION}

The study was conducted in the workplace setting using case-control design. Probability that not all cases in the workplace can be covered and the likelihood of information or recall bias were the weaknesses of the 
study. Efforts to minimize these weaknesses were conducted through active case finding and data confirmation using workers'occupational and medical records.

The case-control design implemented contribute some strengths, such as the ability to directly consider all risk factors experienced by respondents in order to develop prediction model for the risk of work-related LBP. Conducted retrospectively made this study feasible in terms of researcher's limited resources and time.

The results stated that workers within the age group of over 4 years are 2.45 times higher of developing LBP compared to those belong in younger age groups. These finding is similiar to the study conducted by Plowman in 1992 which concluded that the occurences of LBP pain is mostly found in adults with age ranging between 25 to 60 years old, and 40 years old with the highest number of occurences. Degeneration in the structur of intervertebral discs and bones can be considered as the underlying cause of this finding. In addition, Miller in 1998 stated that the tear in annulus increase in size as the person grows older.

Workers who performed sport activites irregularly are facing risk of developing LBP 3 times higher than those who have regular sporting habit. This finding were similar with other studies, and doing sport 3 times/week, for a minimum of 20 minutes were found to increase vitality and decrease the possibility of suffering low back pain. Sport activities could be done in the form of walking, bicycling, swimming, or jogging. ${ }^{11}$

Workers who have served for over 18 years are having twice as high risk in developing LBP compared to those who served less. Working period is identic to cumulative exposure, and the more exposure received by the workers, the higher the risk they had for suffering low back pain. ${ }^{12,13}$

Constricted workplace setting increase the risk of low back pain 4.52 times higher, which most likely resulted from the difficulty to move by the workers which eventually lead to awkward position in performing their tasks.

The eight biomechanical factors studied were all variables related to LP. Those variables are: (a) unnatural working postures, (b) repetitive movements, (c) awkward bending, (d) awkward waist twisting, (e) awkward lifting over the shoulder, (f) awkward manual lifting and handling, (g) overuse of back muscles, and (h) resting period. Workers with awkward bending working position have 25 times risk of developing LBP compared to those without the position. This study showed higher likelihood compared to other 3 studies conducted in Indonesia (with the result of 2.3-7.3), as well as 18 others condicted in Europe (with the result of 1.1-8.1) ${ }^{14}$ These differences might be resulted from certain aspects, such as the difference of the duration of work per day, in Indoensia workers performed their tasks for over 10 hours, whereas in Europe the duration of work is 8 hours per day. Awkward waist twisting produced 38 times higher risk in developing LBP. These finding were contradicted by the studies of $\operatorname{Adnan}^{15}$ which stated that waist twisting did not increase the risk of LBP. On the other hand, similar studies conducted in Europe in 2004 supported this finding.

This study revealed that overuse of back muscle would increase the risk of low back pain 3 times higher. The overuse of back muscle would decrease muscle's endurance due to excessive lactic acid and oxygen depletion in muscle cells. This condition would induce the pain receptors and caused sense of discomfort in the back area, which would further be diagnosed as workrelated LBP. ${ }^{17}$

Lack of rest, identified by the insufficient resting period, would increase the likelihood of developing low back pain 5 times higher compared to other workers who are well-rested. This phenomenon might be caused by the lack of recovery period in the muscle cells which would lead to oxygen depletion and induce a sense of pain, one of the main symptoms of low back pain., ${ }^{9,13}$ Insufficient period of resting could also decrease the amount of oxygen inhaled through the respiratory system (V02max) which would caused ischemia in the muscle tissue and produce pain in the back muscle diagnosed as LBP. ${ }^{18}$

Working stress caused by a sense of responsibility to others would increase the risk of LBP 3 times higher. This finding is similar to other study conducted by Herespagtiani in 2008 which stated that work stress due to a sense of responsibility to others can increase the likelihood of mental and emotional disorders in the form of anxiety and depression, which would increase the sensitivity to sense of pain experienced in the back area, thus inducing the symptoms of LBP. ${ }^{16}$

The main cause of LBP can be found using multivariate analysis on various variables serving as risk factors, awkward bending, awkward waist twisting, working period of over 18 years, irregular sport activities, unnatural working posture, awkward manual lifting and handling. All of the variables mentioned above were components of prediction model for the risk of LBP. Considering that all the variables have been included, the prediction model for the risk of LBP could be used as a guiding tool to develop instruments used in medical check-up.

Instruments to be used in medical check-up should take into consideration all of the variables: 1) Bending $>45^{\circ}$ without the effort to bring the item close to the 
body; and reaching for items on the ground without flexing the knees; with duration of bending $>20-30 \%$ in a single work shift. If such condition occurs, a 2.50 score is added. 2) Irregular sport activity, with less than 3 times a week and duration of less than 20 minutes, are added a 2.50 score. 3) Unnatural working postures are added a 2.00 score. 4). Awkward waist twisting are added a 1.75 score. 5). Awkward manual lifting and handling are added a 1.50 score. 6). Working period of $>18$ years are added 1.00 score

In this instrument model, workers have risk score ranging between $0-11.25$. Using ROC curve a risk score of 3 could be used as a cut-off point in distinguishing workers with high risk and low risk of LBP.

It is concluded that biomechanical determinants contribute to higher risk of LBP compared to host and environment factors. Six variables ( 2 host variables and 4 biomechanical variables) were concluded as the main determinants; awkward bending, irregular sport activities, awkward waist twisting, unnatural working postures, awkward manual lifting and handling, and working period of over 18 years. Prediction score of $\leq 3$ has low risk and score of $>3$ has high risk of developing LBP.

\section{REFERENCES}

1. Rani H. Analisis hubungan faktor psikososial dan faktor lain di lingkungan kerja dengan nyeri pungung bawah psikogenik di perusahan migas X, Balikpapan, Kalimantan Timur, 2008. [Tesis]. Jakarta:Universitas Indonesia; 2008. [Indonesian]

2. Direktorat Bina Kesehatan Kerja, Direktorat Bina Kesehatan Masyarakat, Departemen Kesehatan RI, Strategi Nasional Kesehatan Kerja di Indonesia, Katalog 613.63 Ind Jakarta: Departemen Kesehatan; 2007. [Indonesian].

3. Anthony H Wheeler. MD. Pathophysiology of chronic back pain. Pain and orthopedic neurology, Charlotte, North
Carolina, 2007 [cited in 2007 July 9]. Available on: http:// wwwemedicine.com/neuro/topic5 | $6 \mathrm{htm}$

4. Mardono M, Sidartha P. Neurologi dasar. Ed.6. Jakarta: Dian Rakyat 1997 [Indonesia]

5. Elders L A M, van der Beek A J, Frings-Dresen. Effectiviteit van warkanpassingen bijwerhwrvatting na klachten aan het bewegingsapparaat. Tijdschrift voor Bedrijf- eri Verzekeringsgeneeskunde 8: 137-43 [Dutch]

6. Danakusuma M. Pengantar Kesehatan masyarakat dan kedokteran komunitas. Jakarta: Ikatan Dokter Indonesia; 1997[Indonesian]

7. Chaffin B D, Anderson J B G, Martin J B, Occupational Biomechanics. Ed.4. New Jersey: John Wiley \& Sons, Inc. 2006.

8. Linton S. Review of psychological risk factors in back and neck pain, Spine, 2000; 25:1148-56.

9. Roland, MO. Low back pain in adult. The back book. London: The Stationary Office. 2002.

10. Jurgen C Abela. A case of acute low back pain. Malta Med J, 2004;16. Available on: http://www.um.edu.mt/umms/ $\mathrm{mmj} / 16 \_01 \_11$

11. Kramer J. Intervertebral disk disease. Stutgent Georg Thiome Verlag. 1990.

12. Jill PG Urban, Sally Roberts. Degeneration of the vertebral disc. Arthritis ResTher. 2003; 5(3);120-30

13. Tarwaka, Bakri SHA, Suadiajeng L. Ergonomi untuk keselamatan, kesehatan kerja dan produktivitas. Surakarta:UNIBA Press, 2004; 117-31

14. Siahaan H. Manajemen risiko, konsep, kasus dan implementasi. Cetakan ke 1. Jakarta. PT Gramedia. 2007. [Indonesia]

15. Adnan S. Hubungan antara sikap tubuh waktu bekerja dengan nyeri punggung bawah pada pengrajin pelat logam di Citeureup, Kabupaten Bogor. [Tesis]. Jakarta:Universitas Indonesia;2003 [Indonesia]

16. Deyo AR, Weinstein NJ. Low back pain. Primary care. N Engl J Med.2001;5:363-70

17. Everett S Hills, Mechanical low back pain. 2006, Jun 28. http://www. emedicine.com/pmr/TOPIC73

18. Patel AT, Ogle AA. Diagnosis and management of acute low back pain. Available on: http://familydoctor.org/online/ famdocen/home/common/pain/treatment/20000315/17779. html 8050 